\section{RSP}

http://www.rsp.fsp.usp.br/
Revista de Saúde Pública

\title{
Major depressive episode among university students in Southern Brazil
}

\author{
Betina Daniele Flesch' (iD, Gbènankpon Mathias Houvèssou' (iD), Tiago Neuenfeld Munhoz',"11 (iD), \\ Anaclaudia Gastal Fassa' iD \\ I Universidade Federal de Pelotas. Faculdade de Medicina. Programa de Pós-graduação em Epidemiologia. \\ Pelotas, RS, Brasil \\ " Universidade Federal de Pelotas. Faculdade de Medicina. Curso de graduação em Psicologia. Pelotas, RS, Brasil
}

\section{ABSTRACT}

INTRODUCTION: Depression is the leading cause of disability around the world, and it has been increasingly affecting young people. This study evaluates the prevalence and factors associated with major depression in university students, with emphasis on the influence of the academic field, chosen study area and the environment they are inserted.

METHODS: A census of students who entered the university in the first semester of 2017 was held at a university in Southern Brazil. The outcome of major depressive episode was evaluated using the Patient Health Questionnaire-9, considered when the individual had five or more depressive symptoms for at least one week. Its prevalence was estimated, and the associated factors were examined by the hierarchical multivariable analysis using the Poisson regression model.

RESULTS: A total of 32\% (95\% confidence interval 29.9-34.2) of university students presented a major depressive episode, and the problem was more frequent among women (prevalence ratio $[\mathrm{PR}]=1.59)$; people aged 21 to 23 years $(\mathrm{PR}=1.24)$; those with a family history of depression $(\mathrm{PR}=1.27$ ); minorities' sexual orientation (homosexuals, $\mathrm{PR}=1.64$, and bisexuals, $\mathrm{PR}=1.69$ ); who lived with friends or colleagues ( $\mathrm{PR}=1.36)$; students in the area of applied social and human sciences $(\mathrm{PR}=1.28)$, and linguistics, language and literature, and art $(\mathrm{PR}=1.25)$. The worst academic performance $(\mathrm{PR}=2.61)$, alcohol abuse $(\mathrm{PR}=1.25)$, and illicit drug use $(\mathrm{PR}=1.30)$ were also positively associated with major depressive episode.

CONCLUSION: In addition to individual, family, and behavioral aspects, already described as risk factors for major depressive episodes in the general population, academic aspects also influence the occurrence of depression among university students. Considering the high prevalence of major depressive episode and its negative impact on health, public and institutional policies are necessary to focus on students' mental health promotion and care.

DESCRIPTORS: Students, psychology. Higher Education. Depression, epidemiology. Depressive Disorder, epidemiology. Risk Factors. Mental Health. 


\section{INTRODUCTION}

Depression is the main health problem and the leading cause of disability worldwide, reaching more than 300 million people and having increased 18\% from 2005 to $2015^{1}$. According to the 2013 National Health Survey (NHS), the prevalence of self-reported depression diagnosis in adults was higher in Rio Grande do Sul (13.2\%) than in Brazil (7.6\%) ${ }^{2}$.

The literature also points out this problem among university students, showing that 15 to $25 \%$ of them develop some type of mental disorder during graduation, and depression is one of the most prevalent ones ${ }^{3}$. Both in Brazil and in other countries, when depression was evaluated in university students by the DSM- 5 and the ICD-10, the prevalence varied between 5 and $15 \%$, and when it was tracked with questions about the depressive symptomatology, the results varied from 30 to $50 \%^{6,7}$.

As in the population studies, the prevalence of depression among university students is higher in women, older adults and people of low socioeconomic status. However, among university students, depression may be related to life stage transitions. It was positively associated with moving away from family and needing to adapt to the university environment ${ }^{5-8}$. In addition, academic requirements, financial difficulties, and concerns about the future can act as triggers for the depressive symptomatology ${ }^{9,10}$.

The major depressive episode (MDE) is characterized by the presence of depressed, empty or irritable mood, accompanied by somatic and cognitive changes that significantly affect the individual's functional capacity for at least one week ${ }^{11}$. MDE leads individuals to isolationism, impacting daily activities, causing the reduction in physical activities, influencing appetite, either with gain or weight loss, and negatively affecting performance and academic productivity ${ }^{12}$. Besides, studies indicate that depression is associated with suicidal ideation and suicide risk ${ }^{3,13}$. However, despite the high prevalence of depression and its negative impact on the quality of life, part of the population does not recognize depressive symptoms as a disease, which slows its diagnosis and treatment, hindering suicide prevention ${ }^{9}$.

Studies that measure the occurrence of depression among university students use different measurement instruments and cutoff points, being sometimes restricted to some courses, which limits the extrapolation of the results to the general population of university students. Few studies detail the intensity and degrees of depression, as well as the main depressive symptoms ${ }^{14}$. In addition, studies address the main depression risk factors, which are common to the general population, without emphasizing specific aspects of university students.

This study evaluates the prevalence and factors associated with major depression in university students, with emphasis on the influence of the academic field, study area and the environment they are inserted.

\section{METHODS}

The Graduate Program in Epidemiology of the Universidade Federal de Pelotas (UFPel) conducted a research consortium entitled Saúde do Estudante Universitário (SEU - University Student Health). As part of this consortium, a cross-sectional census study on undergraduate students was conducted in 80 UFPel in-person courses, with admission in the first semester of 2017 and with students still enrolled in the second half of 2017. Data were collected covering all masters' dissertation themes of the program, thus optimizing human and financial resources ${ }^{15}$.

The number of students needed to evaluate the prevalence of major depressive episode was 1,328 , considering the $30 \%$ prevalence estimate, a margin of error of two percentage points, the confidence level of $95 \%$, and adding $10 \%$ for losses. For the association calculation, the 
largest sample size required was 1,291 to examine the association with the economic level. The following items were used as parameters: $80 \%$ statistical power, $95 \%$ confidence interval, exposed/unexposed ratio of 7:3, 15\% prevalence of major depressive episode in non-exposed, and 1.5 relative risk, adding $10 \%$ for losses and $15 \%$ for the confounding factor control. The sample size calculation was performed in OpenEpi, version 3.01.

To meet the research objectives of all master's students involved in the consortium, 2,706 students were included in the study, representing all eligible students. Undergraduates under the age of 18 years were excluded, as well as those who gave up or performed enrollment locks throughout the research period.

Among the independent variables, the considered demographic aspects were biological sex (male or female), age (in full years, categorized in 18, 19-20, 21-23 and $\geq 24$ years old), skin color or ethnicity (white, black, mixed or other); the family history of self-reported depression (yes or no), considering family members "those with whom you have daily coexistence or blood tie," and the predominant sexual orientation (heterosexual, bisexual, asexual or homosexual). Socioeconomic status was also investigated, classified according to the Associação Brasileira de Empresas de Pesquisa (ABEP - Brazilian Association of Research Companies) ${ }^{16}$ (A, B, C or D/E) and measured by the consumer goods, the region of origin (Pelotas, another city in Rio Grande do Sul, another state of Brazil, or another country), and with whom the university student lives (alone, parents or family, spouse, friends, or colleagues). In addition, the examined academic aspects were related to the area of knowledge of the course (exact and land/agrarian sciences and engineering, health and biological sciences, applied social and human or linguistic sciences, language and literature, and arts) and to the self-reported academic performance (bad/very bad, moderate, good or very good/excellent). The following behavioral variables were also evaluated: smoking (smoker, former smoker and non-smoker), harmful alcohol use according to the Audit considering the cutoff point $\geq 8$ points (yes or no), and consumption of illicit substances in the last month (yes or no).

MDE was evaluated using the algorithm of the questionnaire Patient Health Questionnaire-9 (PHQ-9), which is a validated instrument in the population of Pelotas ${ }^{17}$, because it allows the diagnosis of MDE and its concise structure, and it is easy to understand. MDE was considered as the presence of five or more symptoms in the two weeks prior to the data collection, with at least one depressed mood or anhedonia, with each having occurred during "one week or more" or "almost every day," except for symptom nine ("In the last two weeks, how many days did you think about hurting yourself or that it would be better to be dead?"), for which the occurrence was considered for "less than a week," "a week or more" or "almost every day." The prevalence of depression was also evaluated, according to severity levels, classified as without depression (1 to 4 points), mild depression (5 to 9), moderate depression (10 to 14), moderately severe depression (15 to 19), or severe depression (20 to 27 points) ${ }^{18}$.

A pilot study was conducted in October 2017 among students who entered the second semester of 2016, with self-applied questionnaire on paper, to evaluate and detect possible interpretation failures, the time required to answer the questionnaire, and the logistical aspects of the study.

The study data collection was performed between November 2017 and July 2018, by self-applied and anonymous questionnaire in tablets, using the Research Electronic Data Capture program (RedCap), or paper, when the many students exceeded the number of available tablets at the time or in case of the student's preference. The masters' students actively searched the students in the classroom after the consent of the coordinator and of the professor of the course. When they were not found in the classroom, due to absence or because they were not enrolled in that discipline, they were sought on another day, preferably in another course. To perform a good quality data collection, an application 
manual providing the possible doubts of the instrument was elaborated, the master's students were trained to supervise the field work, weekly meetings were held aiming at the standardization of data collection, and partial data were analyzed to identify any early problems in the questionnaire.

Data were analyzed using the Stata program, version 12.0. First, a descriptive analysis of the outcome and the independent variables was performed to characterize the sample; subsequently, the prevalence of depression was estimated with the respective confidence interval of $95 \%(95 \% \mathrm{CI})$. A hierarchical multivariate analysis was conducted using the Poisson regression model and adjustment for robust variance. In the first level, demographic and socioeconomic variables were included; in the second level, the region of origin, with whom they live, and the academic aspects (the area of knowledge and the academic performance) were included; and in the third level, the behavioral variables.

The associations of the independent variables with the outcome were estimated by the prevalence ratios and their respective 95\% confidence intervals, the heterogeneity chi-square test, and when possible, the linear trend test. In the multivariate analysis, aiming to adjust for confounding factors, the associated outcome variables with $\mathrm{p}$-value $<0.20$ were maintained in the model. The variables that presented a $p$-value $<0.05$ were considered associated.

The project was approved by the Research Ethics Committee of the Faculdade de Medicina of UFPel, in October 2017 with no. 79250317.0.0000.5317. The theme of the study was explained to the students, and they were guaranteed the right to non-participation and confidentiality of the provided information. The questionnaire was only applied after the signing of the informed consent form.

\section{RESULTS}

A total of 1,865 students were interviewed; 1,827 of them answered all PHQ-9 questions and were included in these analyses. Considering the percentage of eligible students who entirely answered the PHQ-9, the response rate was $67.5 \%$. In the study population, $55 \%$ were women, $34.4 \%$ were between 19 and 20 years old, $72 \%$ self-declared whites, $56 \%$ reported a family history of depression, $44 \%$ were of the B economic level according to ABEP, $46 \%$ originated from Pelotas and $35 \%$ originated from other cities in the Rio Grande do Sul, 33\% consumed alcohol and 23\% took illicit substances in the last month. According to the algorithm for diagnosis of the PHQ-9, 32\% (95\%CI 29.9-34.2) presented MDE. Evaluating the depression severity levels ${ }^{18}$, 29.7\% (95\%CI 27.6-31.8) presented mild depression, $22.3 \%$ (95\% CI 20.5-24.3) moderate depression, $15.2 \%$ (95\% CI 13.6-16.9) moderately severe depression, and 15\% severe depression (95\%CI 13.4-17.7), according to Table 1.

In the adjusted analysis, female students (prevalence ratio [PR] = 1.59; 95\%CI 1.37-1.86), and bisexual students ( $\mathrm{PR}=1.69 ; 95 \% \mathrm{CI} 1.44-1.98)$, and homosexuals ( $\mathrm{PR}=1.64 ; 95 \% \mathrm{CI} 1.31-2.06)$ presented an average 60\% risk for MDE. The students aged between 21 and 23 years had a $24 \%$ higher risk (95\%CI 1.01-1.53) compared with the new students aged 18 years, and among those with a family history of depression, the MDE risk was $27 \%$ (95\%CI 1.10-1.47), as shown in Table 2.

Students who reported living with friends and colleagues had a 36\% MDE higher risk (95\%CI 1.05-1.77) compared with those who lived alone. Students of social and human science courses (95\%CI 1.07-1.53) and those of linguistics, language and literature, and art (95\%CI 1.01-1.54) presented an average 25\% MDE higher risk when compared with those of the courses of exact and land/agrarian sciences, and engineering. The academic performance was inversely associated with the MDE occurrence, being 2.6 times higher (95\%CI 1.87-3.64) 
Table 1. Description of the sample according to demographic, socioeconomic, and academic characteristics, and prevalence of major depressive episode (MDE) among university students. Pelotas (RS), Brazil, 2017 ( $\mathrm{n}=1827)$.

\begin{tabular}{|c|c|c|c|}
\hline Variables & $\mathrm{N}(\%)$ & $\%$ MDE & P-value \\
\hline Sex & & & $<0,001$ \\
\hline Male & $820(44,9)$ & 23,3 & \\
\hline Female & $1.005(55,1)$ & 39,1 & \\
\hline Age & & & 0,019 \\
\hline 18 years & $398(21,9)$ & 27,9 & \\
\hline 19-20 years & $624(34,4)$ & 34,5 & \\
\hline $21-23$ years & $422(23,3)$ & 35,8 & \\
\hline 24 or older & $371(20,4)$ & 28,3 & \\
\hline Skin Color/Ethnicity (self-reported) & & & 0,075 \\
\hline White & $1.311(71,8)$ & 30,7 & \\
\hline Black & $240(13,2)$ & 39,2 & \\
\hline Mixed & $243(13,3)$ & 32,1 & \\
\hline Other & $31(1,7)$ & 35,5 & \\
\hline Family history of depression & & & $<0,001$ \\
\hline No & $794(43,5)$ & 26,2 & \\
\hline Yes & $1.030(56,5)$ & 36,5 & \\
\hline Sexual orientation & & & $<0,001$ \\
\hline Heterosexual & $1.361(74,9)$ & 27,1 & \\
\hline Homosexual & $143(7,9)$ & 42,0 & \\
\hline Bisexual & $237(13,0)$ & 54,0 & \\
\hline Asexual & $76(4,2)$ & 32,9 & \\
\hline Socioeconomic level & & & $0,009 a$ \\
\hline A & $261(14,9)$ & 28,4 & \\
\hline B & $773(44,3)$ & 29,8 & \\
\hline $\mathrm{C}$ & $634(36,4)$ & 34,4 & \\
\hline $\mathrm{D} / \mathrm{E}$ & $76(4,4)$ & 40,8 & \\
\hline Region of origin & & & 0,204 \\
\hline Pelotas & $831(45,6)$ & 30,3 & \\
\hline Another city in Rio Grande do Sul & $638(35,0)$ & 31,7 & \\
\hline Another state & $352(19,3)$ & 36,7 & \\
\hline Another country & $3(0,2)$ & 33,3 & \\
\hline Who they live with & & & 0,003 \\
\hline Alone & $229(12,6)$ & 26,6 & \\
\hline Parents or family members & $913(50,1)$ & 31,7 & \\
\hline Spouse & $205(11,3)$ & 26,3 & \\
\hline Friends and colleagues & $476(26,1)$ & 38,3 & \\
\hline Courses (large areas according to CNPq) & & & 0,008 \\
\hline Exact and earth/agrarian sciences, and engineering & $530(29,0)$ & 27,0 & \\
\hline Health and biological sciences & $324(17,7)$ & 30,6 & \\
\hline Applied social and human sciences & $632(34,6)$ & 34,3 & \\
\hline Linguistics, language and literature, and arts & $341(18,7)$ & 37,0 & \\
\hline Academic performance & & & $<0,001$ \\
\hline Terrible & $25(1,37)$ & 84,0 & \\
\hline Very bad & $78(4,3)$ & 56,4 & \\
\hline Moderate & $605(33,1)$ & 36,7 & \\
\hline Good & $729(39,9)$ & 27,7 & \\
\hline Very good & $340(18,6)$ & 23,5 & \\
\hline Excellent & $50(2,7)$ & 32,0 & \\
\hline
\end{tabular}


Table 1. Description of the sample according to demographic, socioeconomic, and academic characteristics, and prevalence of major depressive episode (MDE) among university students. Pelotas (RS), Brazil, 2017 ( $n=1827)$. (Continuation)

\begin{tabular}{|c|c|c|c|}
\hline Variables & $\mathbf{N}(\%)$ & $\% \mathrm{MDE}$ & P-value \\
\hline Smoking & & & $<0,001$ \\
\hline Non-smoker & $1.338(73,3)$ & 28,3 & \\
\hline Former smoker & $201(11)$ & 47,8 & \\
\hline Smoker & $287(15,7)$ & 38,3 & \\
\hline Alcohol abuse $^{b}$ & & & $<0,001$ \\
\hline No & $1.118(66,8)$ & 27,7 & \\
\hline Yes & $557(33,3)$ & 40,6 & \\
\hline Use of illicit substances (last month) & & & $<0,001$ \\
\hline No & $1.404(76,9)$ & 28,5 & \\
\hline Yes & $423(23,1)$ & 43,7 & \\
\hline \multicolumn{4}{|l|}{ MDE diagnosis by PHQ-9 } \\
\hline No & $1.242(68,0)$ & \multicolumn{2}{|c|}{$65,9-70,2^{\mathrm{c}}$} \\
\hline Yes & $585(32,0)$ & \multicolumn{2}{|c|}{$29,8-34,1^{\mathrm{c}}$} \\
\hline \multicolumn{4}{|l|}{ Depression severity levels by the PHQ-9 } \\
\hline No depression & $326(17,8)$ & \multicolumn{2}{|c|}{$16,2-19,7^{c}$} \\
\hline Mild depression & $542(29,7)$ & \multicolumn{2}{|c|}{$27,6-31,8^{c}$} \\
\hline Moderate depression & $408(22,3)$ & \multicolumn{2}{|c|}{$20,5-24,3^{c}$} \\
\hline Moderately severe depression & $277(15,2)$ & \multicolumn{2}{|c|}{$13,6-16,9^{c}$} \\
\hline Severe depression & $274(15,0)$ & \multicolumn{2}{|c|}{$13,4-17,7^{\mathrm{c}}$} \\
\hline
\end{tabular}

CNPq: Conselho Nacional de Desenvolvimento Científico e Tecnológico; PHQ-9: Patient Health Questionnaire-9; $95 \% \mathrm{Cl}: 95 \%$ confidence interval

a P-value for trend.

${ }^{\mathrm{b}}$ For up to 152 individuals, information about at least one variable could not be obtained.

95\% confidence interval.

among students who reported "very poor/poor" performance when compared with those who had "excellent/very good" performance. The alcohol abuse ( $\mathrm{PR}=1.25 ; 95 \% \mathrm{CI} 1.08-1.45)$ and the use of illicit substances in the last 30 days ( $P R=1.30$; 95\%CI 1.11-1.52) were also MDE risk factors (Table 2).

\section{DISCUSSION}

Among the surveyed university students, $32 \%$ had MDE and the problem was more frequent among women, aged 21 to 23 years, with a family history of depression, with minorities' sexual orientation (homosexuals and bisexuals), who lived with friends and colleagues, and students in the area of applied social and human sciences, as well as linguistics, language and literature, and arts. The worst academic performance, the alcohol abuse, and the illicit drug use were also positively associated with MDE.

Most studies on Brazilian university students used convenience samples and were limited to specific courses, especially to the health area ${ }^{14,19-21}$. The most used instrument to measure the prevalence of depression symptoms was the Beck Depression Inventory (BDI). A survey that evaluated 1,039 students from health courses in a southern Brazilian city indicated a prevalence of mild, moderate, or severe depressive symptomatology in $28.3 \%$ of the students ${ }^{22}$. Among the studies that investigated the diagnosis of depression, De Melo Cavestro and Rocha ${ }^{23}$ evaluated 342 university students of health courses using the Mini International Neuropsychiatric Interview (Mini) and observed the $10.5 \%$ MDE prevalence ${ }^{3}$. Vasconcelos et al. ${ }^{23}$ evaluated a convenience sample of 234 medical students through the Hospital Anxiety and Depression Scale (HADS) and found suggestive symptoms of the disorder at 5.6\%. 
Table 2. Factors associated with major depressive episode among university students. Pelotas (RS), Brazil, 2017.

\begin{tabular}{|c|c|c|c|c|}
\hline \multirow{2}{*}{ Variables } & \multicolumn{2}{|c|}{ Crude analysis } & \multicolumn{2}{|c|}{ Adjusted analysis } \\
\hline & PR $(95 \% \mathrm{Cl})$ & P-value & PR $(95 \% \mathrm{Cl})$ & P-value \\
\hline \multicolumn{5}{|l|}{$1^{\text {st }}$ level } \\
\hline Sex & & $<0,001$ & & $<0,001$ \\
\hline Male & Ref & \multicolumn{3}{|c|}{ Ref } \\
\hline Female & $1,68(1,45-1,94)$ & \multicolumn{3}{|c|}{$1,59(1,37-1,86)$} \\
\hline Age & & 0,021 & & 0,068 \\
\hline 18 years & Ref & \multicolumn{3}{|c|}{ Ref } \\
\hline 19 and 20 years & $1,24(1,02-1,50)$ & \multicolumn{3}{|c|}{$1,22(1,00-1,48)$} \\
\hline 21 to 23 years & $1,28(1,05-1,57)$ & \multicolumn{3}{|c|}{$1,24(1,01-1,53)$} \\
\hline 24 or older & $1,02(0,81-1,27)$ & \multicolumn{3}{|c|}{$1,03(0,81-1,30)$} \\
\hline Skin Color/Ethnicity & & \multicolumn{2}{|l|}{0,026} & 0,063 \\
\hline White & Ref & \multicolumn{3}{|c|}{ Ref } \\
\hline Mixed & $1,06(0,88-1,28)$ & \multicolumn{3}{|c|}{$1,13(0,94-1,37)$} \\
\hline Black/other & $1,28(1,07-1,53)$ & \multicolumn{3}{|c|}{$1,23(1,02-1,49)$} \\
\hline Family history of depression & & $<0,001$ & & 0,008 \\
\hline No & Ref & \multicolumn{3}{|c|}{ Ref } \\
\hline Yes & $1,39(1,21-1,61)$ & \multicolumn{3}{|c|}{$1,27(1,10-1,47)$} \\
\hline Sexual orientation & & $<0,001$ & & $<0,001$ \\
\hline Heterosexual & Ref & \multicolumn{3}{|c|}{ Ref } \\
\hline Homosexual & $1,55(1,25-1,91)$ & \multicolumn{3}{|c|}{$1,64(1,31-2,06)$} \\
\hline Bisexual & $1,99(1,72-2,31)$ & \multicolumn{3}{|c|}{$1,69(1,44-1,98)$} \\
\hline Asexual & $1,21(0,87-1,69)$ & \multicolumn{3}{|c|}{$1,18(0,85-1,63)$} \\
\hline Socioeconomic level & & \multicolumn{2}{|l|}{$0,009^{a}$} & $0,081^{\mathrm{a}}$ \\
\hline A & Ref & & Ref & \\
\hline B & $1,05(0,84-1,31)$ & & $1,05(0,85-1,30)$ & \\
\hline $\mathrm{C}$ & $1,21(0,97-1,51)$ & & $1,14(0,92-1,42)$ & \\
\hline $\mathrm{D} / \mathrm{E}$ & $1,44(1,03-2,01)$ & & $1,32(0,93-1,86)$ & \\
\hline $2^{\text {nd }}$ level & & & & \\
\hline Who they live with & & 0,003 & & 0,037 \\
\hline Alone & Ref & & Ref & \\
\hline Parents or family members & $1,19(0,94-1,50)$ & & $1,23(0,95-1,58)$ & \\
\hline Spouse & $0,99(0,72-1,35)$ & & $1,00(0,72-1,39)$ & \\
\hline Friends and colleagues & $1,43(1,12-1,82)$ & & $1,36(1,05-1,77)$ & \\
\hline Courses (large areas according to CNPq) & & 0,009 & & 0,038 \\
\hline Exact and earth/agrarian sciences, and engineering & Ref & & Ref & \\
\hline Health and biological sciences & $1,13(0,91-1,41)$ & & $1,10(0,89-1,36)$ & \\
\hline Applied social and human sciences & $1,27(1,07-1,52)$ & & $1,28(1,07-1,53)$ & \\
\hline Linguistics, language and literature, and arts & $1,37(1,12-1,67)$ & & $1,25(1,01-1,54)$ & \\
\hline Academic performance & & $<0,001$ & & $<0,001$ \\
\hline Excellent/very good & Ref & & Ref & \\
\hline Good & $1,13(0,91-1,39)$ & & $1,15(0,89-1,48)$ & \\
\hline Moderate & $1,49(1,22-1,83)$ & & $1,51(1,18-1,95)$ & \\
\hline Poor/terrible & $2,56(2,04-3,22)$ & & $2,61(1,87-3,64)$ & \\
\hline $3^{\text {rd }}$ level & & & & \\
\hline Alcohol abuse & & $<0,001$ & & 0,003 \\
\hline No & Ref & & Ref & \\
\hline Yes & $1,46(1,27-1,68)$ & & $1,25(1,08-1,45)$ & \\
\hline Use of illicit substances (last month) & & $<0,001$ & & 0,001 \\
\hline No & Ref & & Ref & \\
\hline Yes & $1,53(1,34-1,76)$ & & $1,30(1,11-1,52)$ & \\
\hline
\end{tabular}

PR: prevalence ratio; 95\%Cl: 95\% confidence interval; CNPq: Conselho Nacional de Desenvolvimento Científico e Tecnológico.

a P-value for trend. 
No studies using the PHQ-9 among university students in Brazil were found. In this study, the prevalence of depression was higher than among university students in other countries that used the PHQ-9. In Australia, it was 7.9\% ${ }^{5}$. In England, the prevalence of severe depression was $5.6 \%$ for medical students and $12.7 \%$ for other courses, while moderate depression was $10.8 \%$ among medical students and $17.7 \%$ in other courses ${ }^{24}$. The study by Leppink et al. ${ }^{25}$, conducted in the United States using the PHQ-9, found a 37.7\% prevalence for mild to moderate depressive symptoms and $4.4 \%$ for severe depressive symptoms, also lower than that found in this study.

The 50\% higher risk of MDE among women is consistent with the literature, which points to a large health disparity between sexes, reaching a peak in adolescence $e^{4,5,13,14,26,27}$. The sex gap may be directly related to vulnerability, prejudice, and sex discrimination, and because women report and better recognize depressive symptoms seeking more help for health problems than men, as well as because they often face multiple journeys, taking care of their families, work, and study ${ }^{28}$.

The highest prevalence of MDE among university students was found in the range of 21 to 23 years of age, similar to that observed by other authors who detected the highest prevalence of depression among older students, aged 20 years or older ${ }^{5,8}$. Olsson and Von Knorring ${ }^{29}$ observed that $25 \%$ of adults with depressive disorders report having their first depressive episode before the age of 18 years.

The positive association between the presence of family history of depression and MDE is in accordance with the literature ${ }^{30,31}$. While some studies claim that the relationship between family history and depression is genetic, others consider that it is more related to the family life ${ }^{32}$. Bahls et al. ${ }^{33}$ pointed out in their systematic review that the family history of depression is the main risk factor for its development among children and adolescents, increasing it by up to three times. Homosexuality and bisexuality, sexual orientation of minorities, were risk factors for MDE in this study, agreeing with the literature findings ${ }^{25,34}$. The higher occurrence of depression in the population with minority sexual orientation may be related to prejudice, lack of acceptance, and stigmatization imposed by the society, as well as to the family distancing and lower support network ${ }^{34}$.

This study found the highest prevalence of MDE among students who reported living with friends or colleagues, which may be related to the distance of their families and support network, as well as the need to adapt to the routine of shared republics, pensions and student housing ${ }^{7,23}$.

Although most studies found in the literature specifically deal with university students from health courses, our study observed the highest MDE prevalence among students in the areas of humanities, arts and linguistics, a result similar to another Brazilian study ${ }^{14}$. The higher prevalence of depression in humanities students may be related to particular academic requirements and routines, and/or students' greater difficulty to face them ${ }^{14}$. Previous studies have observed that the course dissatisfaction of the students was also positively related to the MDE and MDD (major depressive disorder) occurrence ${ }^{27,30}$.

A negative relationship was observed between academic performance and MDE, as already described in the literature. The good academic performance is a significant marker of the students' success and development, indicating a positive response to competitiveness and to the high level of demand in the university. This association is subjected to a two-way direction, since the already depressed student tends to find greater difficulties in performing their daily activities, as well as being depressed by the poor performance achieved. In addition, students with MDE can make a more critical and pessimistic self-assessment ${ }^{4,7,12,27}$.

The positive association between illicit drug use, alcohol, and depression is consistent with the literature findings ${ }^{23,26}$. The causal relationship between these outcomes is not fully enlightened, and it is described that neurophysiological and metabolic alterations resulting from alcohol exposure may be related to the depression development ${ }^{35}$. Drug use may be related to MDE as both a risk factor for the development of biochemical 
and neurophysiological alterations, as well as because it is a marker of the student's vulnerability. The literature reports that illicit drug use is related to suicidal thoughts, sadness, loneliness, and difficulty sleeping, and that the presence of alcohol abuse doubles the chance of depressive disorder occurrence, being the opposite also true ${ }^{35,36}$. Thus, considering this cross-sectional study, this association may be affected by reverse causality and/or two-way direction.

This study found no association between the economic level and skin color with MDE, although these associations are widely reported in the literature. The existing quota policy in the institution seeks to expand the number of students from public schools, blacks, and aborigines. Although quota students come from the most vulnerable groups, the arduous selection process makes them the most privileged among their peers, those most proactive or better able to face adversity, which may explain the absence of the association with $\mathrm{MDE}^{4,5,31}$.

The change of school semester in the data collection period and the course withdrawal or abandonment by students implied a considerable loss, more concentrated in men and older individuals, for courses in exact and land/agrarian sciences and engineering, which can cause inaccuracies in the prevalence estimation. Although this study advances in relation to the literature by evaluating all courses, the external findings validity is limited because it refers to a specific university.

As positive aspects, the high descriptive and screening value for the mental health of students stands out, which will serve as a basis for reception and for interventions to be performed in the university population, and the self-applying method of the instrument enables students to address sensitive issues, such as MDE and its symptoms. The fact the PHQ-9 was not used in other studies in Brazilian university students limits the comparability of the findings; however, as it was recently validated for the Brazilian population and has the advantage of providing a diagnosis of MDE, it is desirable for future studies to start using this instrument ${ }^{17}$.

In addition to individual, family, and behavioral aspects, similar to those already described as risk factors for MDE in the general population, academic aspects also influence the occurrence of depression among university students. Considering the high prevalence of MDE and its negative impact on health, quality of life, and academic development of university students, public and institutional policies are needed to promote health, especially mental health, as well as a structure to meet the students' demands for adequate healthcare.

\section{REFERENCES}

1. World Health Organization. Mental health atlas 2017. Geneva: WHO; 2018.

2. Stopa SR, Malta DC, Oliveira MM, Lopes CS, Menezes PR, Kinoshita RT. Prevalência do autorrelato de depressão no Brasil: resultados da Pesquisa Nacional de Saúde, 2013. Rev Bras Epidemiol. 2015;18 Supl 2:170-80. https://doi.org/10.1590/1980-5497201500060015

3. Cavestro JM, Rocha FL. Prevalência de depressão entre estudantes universitários. J Bras Psiquiatr. 2006;55(4):264-7. https://doi.org/10.1590/S0047-20852006000400001

4. Santos LR, Veiga F, Pereira A. Sintomatologia depressiva e percepção do rendimento académico no estudante do ensino superior. In: Domingues D, et al, editores. Actas do $12^{\circ}$ Colóquio de Psicologia, Educação, Aprendizagem e Desenvolvimento: Olhares Contemporâneos através da Investigação; jun 2012; Lisboa (PRT). Lisboa: ISPA; 2012:1656-66.

5. Farrer LM, Gulliver A, Bennett K, Fassnacht DB, Griffiths KM. Demographic and psychosocial predictors of major depression and generalised anxiety disorder in Australian university students. BMC Psychiatry. 2016;16(1):241. https://doi.org/10.1186/s12888-016-0961-z

6. Balanza Galindo S, Morales Moreno I, Guerrero Muñoz J. Prevalencia de ansiedad y depresión en una población de estudiantes universitarios: factores académicos y sociofamiliares asociados. Clin Salud. 2009;20(2):177-87. 
7. Pereyra-Elías R, Ocampo-Mascaró J, Silva-Salazar V, Vélez-Segovia E, Costa-Bullón AD, Toro-Polo LM, et al. Prevalencia y factores asociados con síntomas depresivos en estudiantes de ciencias de la salud de una Universidad privada de Lima, Perú 2010. Rev Peru Med Exp Salud Publica. 2010;27(4):520-6.

8. Shamsuddin K, Fadzil F, Ismail WSW, Shah SA, Omar K, Muhammad NA, et al. Correlates of depression, anxiety and stress among Malaysian university students. Asian J Psychiatr. 2013;6(4):318-23. https://doi.org/10.1016/j.ajp.2013.01.014

9. Dutra E. Suicídio de universitários: o vazio existencial de jovens na contemporaneidade. Estud Pesq Psicol. 2012;12(3):924-37. https://doi.org/10.12957/epp.2012.8229

10. Organização Mundial da Saúde. Depressão: uma crise global. Genebra: OMS; 2012.

11. American Psychiatric Association. Manual diagnóstico e estatístico de transtornos mentais - DSM. 5. ed. Porto Alegre: Artmed; 2014.

12. Khanam SJ, Bukhari SR. Depression as a predictor of academic performance in male and female university students. J Pak Psychiatr Soc. 2015;12(2):15-7.

13. Aradilla-Herrero A, Tomás-Sábado J, Gómez-Benito J. Associations between emotional intelligence, depression and suicide risk in nursing students. Nurse Educ Today. 2014;34(4):5205. https://doi.org/10.1016/j.nedt.2013.07.001

14. Victoria MS, Bravo A, Felix AK, Neves BG, Rodrigues CB, Ribeiro CCP, et al. Níveis de ansiedade e depressão em graduandos da Universidade do Estado do Rio de Janeiro (UERJ). Encontro Rev Psicol. 2015;16(25):163-75.

15. Barros AJD, Menezes AMB, Santos IS, Assunção MCF, Gigante D, Fassa AG, et al. O Mestrado do Programa de Pós-graduação em Epidemiologia da UFPel baseado em consórcio de pesquisa: uma experiência inovadora. Rev Bras Epidemiol. 2008;11 Supl 1:133-44. https://doi.org/10.1590/S1415-790X2008000500014

16. Associação Brasileira de Empresas de Pesquisa. Critério de Classificação Econômica da Brasil. São Paulo: ABEP; 2015.

17. Santos IS, Tavares BF, Munhoz TN, Almeida LSP, Silva NTB, Tams BD, et al. Sensibilidade e especificidade do Patient Health Questionnaire-9 (PHQ-9) entre adultos da população geral. Cad Saude Publica. 2013;29(8):1533-43. https://doi.org/10.1590/0102-311X00144612

18. Kroenke K, Spitzer RL, Williams JB. The PHQ-9: validity of a brief depression severity measure. J Gen Intern Med. 2001;16(9):606-13. https://doi.org/10.1046/j.1525-1497.2001.016009606.x

19. Amaral GF, Gomide LMP, Batista MP, Píccolo PP, Teles TBG, Oliveira PM, et al. Sintomas depressivos em acadêmicos de medicina da Universidade Federal de Goiás: um estudo de prevalência. Rev Psiquiatr Rio Gd Sul. 2008;30(2):124-30. https://doi.org/10.1590/S0101-81082008000300008

20. Cecconello WW, Batistella F, Wahl SDZ, Wagner MF. Avaliação de sintomas depressivos e de fobia social em estudantes de graduação. Aletheia. 2013;(42):71-81.

21. Cremasco GS, Baptista MN. Depressão, motivos para viver e o significado do suicídio em graduandos do curso de psicologia. Estud Interdiscip Psicol. 2017;8(1):22-37. https://doi.org/10.5433/2236-6407.2017v8n1p22

22. Sakae TM, Padão DL, Jornada LK. Sintomas depressivos em estudantes da área da saúde em uma Universidade no Sul de Santa Catarina-UNISUL. Rev AMRIGS. 2010;54(1):38-43.

23. Vasconcelos TC, Dias BRT, Andrade LR, Melo GF, Barbosa L, Souza E. Prevalência de sintomas de ansiedade e depressão em estudantes de medicina. Rev Bras Educ Med. 2015;39(1):135-42. https://doi.org/10.1590/1981-52712015v39n1e00042014

24. Honney K, Buszewicz M, Coppola W, Griffin M. Comparison of levels of depression in medical and non medical students. Clin Teach. 2010;7(3):180-4. https://doi.org/10.1111/j.1743-498X.2010.00384.X

25. Leppink EW, Lust K, Grant JE. Depression in university students: associations with impulse control disorders. Int J Psychiatry Clin Pract. 2016;20(3):146-50. https://doi.org/10.1080/13651501.2016.1197272

26. Murillo-Pérez L, Rojas-Adrianzén C, Ramos-Torres G, Cárdenas-Vicente B, Hernández-Fernández W, Larco-Castilla P, et al. Asociación entre el riesgo de depresión mayor y el bajo nivel de actividad física en trabajadores peruanos que cursan estudios universitarios. Rev Peru Med Exp Salud Publica. 2014;31(3):520-4.

27. Iqbal S, Gupta S, Venkatarao E. Stress, anxiety and depression among medical undergraduate students and their socio-demographic correlates. Indian J Med Res. 2015;141(3):354-7. https://doi.org/10.4103/0971-5916.156571 
28. Salk RH, Hyde JS, Abramson LY. Gender differences in depression in representative national samples: meta-analyses of diagnoses and symptoms. Psychol Bull. 2017;143(8):783-822. https://doi.org/10.1037/bul0000102

29. Olsson G, Knorring AL. Adolescent depression: prevalence in Swedish high school students. Acta Psychiatr Scand. 1999;99(5):324-31. https://doi.org/10.1111/j.1600-0447.1999.tb07237.x

30. Sokratous S, Merkouris A, Middleton N, Karanikola M. The prevalence and sociodemographic correlates of depressive symptoms among Cypriot university students: a cross-sectional descriptive co-relational study. BMC Psychiatry. 2014;14(1):235. https://doi.org/10.1186/s12888-014-0235-6

31. Arrieta Vergara KM, Díaz Cárdenas S, González Martínez F. Síntomas de depresión y ansiedad en jóvenes universitarios: prevalencia y factores relacionados. Rev Clin Med Fam. 2014;7(1):1422. https://doi.org/10.4321/S1699-695X2014000100003

32. Ramchandani P, Psychogiou L. Paternal psychiatric disorders and children's psychosocial development. Lancet. 2009;374(9690):646-53. https://doi.org/10.1016/S0140-6736(09)60238-5

33. Bahls SC. Aspectos clínicos da depressão em crianças e adolescentes. J Pediatria (Rio J.). 2002;78(5):359-66. https://doi.org/10.1590/S0021-75572002000500004

34. Ross LE, Salway T, Tarasoff LA, MacKay JM, Hawkins BW, Fehr CP. Prevalence of depression and anxiety among bisexual people compared to gay, lesbian, and heterosexual individuals: a systematic review and meta-analysis. J Sex Res. 2018;55(4-5):435-56. https://doi.org/10.1080/00224499.2017.1387755

35. Boden JM, Fergusson DM. Alcohol and depression. Addiction. 2011;106(5):906-14. https://doi.org/10.1111/j.1360-0443.2010.03351.x

36. Vieira PC, Aerts DRGC, Freddo SL, Bittencourt A, Monteiro L. Uso de álcool, tabaco e outras drogas por adolescentes escolares em município do Sul do Brasil. Cad Saude Publica. 2008;24(11):2487-98. https://doi.org/10.1590/S0102-311X2008001100004

Funding: This study was funded by PROEX CAPES.

Authors' contribution: Study conception and planning: BDF, TNM, AGF. Data collection, analysis and interpretation: BDF, GMH, TNM, AGF. Manuscript development or revision: BDF, TNM, AGF. Approval of the final version: BDF, TNM, AGF. Public responsibility for the content of the article: BDF, GMH, TNM, AGF.

Conflict of Interests: The authors declare no conflict of interest. 